DOI: $10.17516 / 1997-1370-0590$

УДК 330.3:64.01(47+57)“19”

\title{
Households of Post-Soviet Russia (Institutional Analysis): 20 Years After
}

\author{
Rustem M. Nureev* \\ Financial University under the Government of the Russian Federation \\ Moscow, Russian Federation \\ National Research University Higher School of Economics \\ Moscow, Russian Federation
}

Received 27.11.2020, received in revised form 03.03.2020, accepted 10.04.2020

\begin{abstract}
The article discusses the development of views on households in neoclassical, Keynesian and institutional literature. It shows the advantages and disadvantages of each of these approaches. Neoclassicists do not distinguish between individuals and households. Keynesianism analyzed the investment and savings function of households, showed its role in the revenue and expenditure cycle. However, it did not rise to genuine political economy, since it failed to show the behavior of the main social groups and their inherent interests. Institutional economic theory takes a step forward by showing the dependence of households on the social environment. However, real households are limited in collecting and processing information. Moreover, given the differentiation of households, they possess these funds to varying degrees.

The population explosion in developing countries has exacerbated the problem of poverty and has drawn attention to household economies, whose life expectancy has increased in Asia, Africa and Latin America as a result of a sharp reduction in mortality and an increase in life expectancy.

A special section is devoted to the institutional change of households in post-Soviet Russia. It shows what succeeded and failed to achieve over the past thirty years.
\end{abstract}

Keywords: households, consumption and savings, household investment, transition economy, economic sanctions, investment and savings function of households.

The article was prepared based on the results of studies carried out at the expense of budget funds on a state assignment to the Financial University under the Government of the Russian Federation on the topic "Family households as an economic entity".

Research area: economics.

Citation: Nureev, R.M. (2020). Households of post-Soviet Russia (institutional analysis): 20 years after. J. Sib. Fed. Univ. Humanit. Soc. Sci., 13(4), 571-581. DOI: 10.17516/1997-1370-0590.

\footnotetext{
(C) Siberian Federal University. All rights reserved

* Corresponding author E-mail address: nureev50@gmail.com ORCID: 0000-0003-1407-2657
} 


\section{Neoclassical and Keynesian approaches to the analysis of household economics}

The traditional neoclassical theory is characterized by insufficient attention to the problems of household economics. They appear only at the very beginning in the model of the circulation of economic goods. Households are considered as a source of four factors of production: labour, land, capital, and entrepreneurial ability. Households, supplying the necessary resources (labour, land, capital, entrepreneurial ability), receive cash income (wages, rents, interest, profits). Thus, the real flow of economic benefits is complemented by a counter cash flow of income and expenses. The model is usually concretized by including states, as well as leaks and injections.

However, in a number of works, the distinction between the household and the individual is usually not made: they are considered as synonyms. Neoclassical theory is a special case of the theory of rational choice, therefore it treats household as an economic entity that acts completely rationally. In addition, it is usually assumed that the household operates in conditions of complete certainty, that is, it can process any amount of information. It does not violate the rules of the game and norms prevailing in society.

In neoclassical literature, households appear in a section on consumer behaviour theory $^{1}$. Each consumer has three questions: 1. What to buy? 2. How much does it cost? 3. Is there enough money to make a purchase?

To answer the first question, you need to find out the usefulness of the thing for the consumer, to answer the second one you need to examine the price, to solve the third question you need to determine the consumer's income. These three problems - utility, price, and income - constitute the content of the theory of consumer behaviour.

Already in the $19^{\text {th }}$ century it was observed that with the growth of real consumer income, of secondary goods increased faster than consumption of goods of primary necessity. The first researcher to study the impact of changes in income on the structure of consumer spend-

For more details, see: (Hicks, 1988; Menger et al., 1992). ing was the German statistician Ernst Engel (1821-1896).

In accordance with the analysis of Engel's curves in the interpretation of Tornquist, first of all, there is saturation with food products, then with standard-quality manufactured goods and only later with high-quality goods and services. An interesting pattern was noted: even after the transition to the consumption of high-quality goods and services, there is a new surge in demand for standard-quality industrial goods that are used by the consumer for everyday needs.

Thus, all goods are divided into three categories: normal (expenses for which grow with income growth), high-quality (expenses for which are faster than income growth) and low-quality (expenses for which fall as income grows).

The main drawback of neoclassical theory is the lack of analysis of households as a whole, the relationships within them are not actually considered. Neoclassical models do not describe reality as it is. The national characteristics of households also fell outside the scope of neoclassicism. In fact, even if we speak of differences in household behaviour, these differences are perceived as differences of a quantitative type. Households in developed countries appear to be more developed than households in developing countries.

A definite step forward was made by John Maynard Keynes when he tried to consider not only statics, but also some dynamics of their development. This was done primarily in his main work, The General Theory of Employment, Interest, and Money (Keynes). In the book, Keynes introduces new categories of behavioural economics ("propensity to consume", "incentive to invest", "preference for liquidity"), marginal analysis ("marginal propensity to consume", "marginal propensity to save", "marginal efficiency of capital") and macroeconomics ("effective demand", "forced unemployment", "underemployment") (Keynes, 1978).

Keynes sees the main reason for the "economic difficulties" of the modern economic system in the behaviour of business entities, that is, in fact, households. Accord- 
ing to Keynes, consumption is a function of income:

$$
\mathrm{C}=\mathrm{C}(\mathrm{Y}) \text {. }
$$

In this case, the marginal propensity to consume $(\mathrm{MPC}=\Delta \mathrm{C} / \Delta \mathrm{Y})$ changes from zero to one:

$$
0<\mathrm{MPC}<1 .
$$

The marginal propensity to consume shows how consumption changes with an increase (decrease) in disposable personal income by one monetary unit (dollar, yen, franc, etc.). As income rises, marginal propensity to consume decreases. Of course, this position of Keynes does not apply to different groups of consumers to the same extent: to a greater extent it applies to people with low and middle incomes, and to a lesser extent it applies to the richest audience, whose basic needs are already fully satisfied. The change in income of this group of the population is not so strongly reflected in its propensity to consume.

The consumption function manifests itself differently during periods of crisis and during periods of recovery and depends on the general rate of economic development of society. Nevertheless, it is difficult to deny the legitimacy of the tendency observed by J.M. Keynes. Statistical checks carried out later by L. Klein and $\mathrm{M}$. Friedman confirmed the validity of the assumption of J.M. Keynes. In particular, for the short-term period, the marginal propensity to consume turned out to be $0.57-0.60$, and for a longer period it was noticeably higher -0.82 0.839 (Stoleru, 1974).

"Effective demand" acts as the root cause of achieving economic equilibrium. Keynes formulates three ways to deal with inefficient demand:

- A more even distribution of national income is achieved through active fiscal policy;

- The policy of public works expands the possibilities of state enterprise; vestment.

- Monetary policy stimulates private in-

Keynes specifically analyses the motives for refusing to spend money: a transaction motive, a precautionary motive, a speculative motive since accumulation and thriftiness reduce effective demand. Keynes emphasized the importance of the multiplier, which he borrowed from Richard Ferdinand Kahn (1905-1989), who investigated the impact of investment growth on employment. Keynes transformed this idea into an income multiplier showing how a small change in investment affects income change. According to Keynes, money is not just a veil over deals, but a source of energy that makes a market economy work. Relations between people and goods, expressed in monetary terms, acquire an independent existence and significance, which in a mixed economy can no longer be ignored, as classical economists did.

In The General Theory of Employment, Interest, and Money (1978), Keynes poses the problem of leaks and injections in the process of macroeconomic circulation of income-expenses. Later, the Nobel laureates M. Friedman (1957) with his concept of permanent income and F. Modigliani (1970) with his concept of a life cycle developed and elaborated this theory. Violation of the income-expenditure circle slows down the economic development of countries. Therefore, it is necessary to identify the causes of deviations between leaks and injections, the extent of these deviations and their consequences.

At the same time, B. Seligman believed that Keynes's economic theory failed to rise to the level of genuine political economy. This happened because Keynes theory considered the behaviour of people to be the driving force of the economic process. He defined economic relations as the result of relations between people and groups. Therefore, in order to change the behaviour of economically important groups, it is necessary to effectively use government policy. However, in his conception, none of these groups has ever shown its own social interests, inherent only to it. According to B. Seligman, Keynes's theory includes too many technical elements and does not investigate the social causes behind them. Keynes sees the main task in achieving economic equilibrium, being carried away by the quantitative side of economic processes, but not by their origin and functioning mechanism. Keynes's social philosophy is based on a belief in continuous 
economic development, which, however, does not imply absolute equality (Seligman, 1968).

Unlike neoclassical theory, institutional theory distinguishes between individuals and households. The views of the latter are not equivalent to the views of individuals. Institutional theory understands that households are dependent on the social environment. This social environment is different in different societies, so households must take into account the uncertainty of external conditions that are constantly changing. This poses the problem of collecting the necessary information. However, real households are limited in collecting and processing information. It depends on the level of education and training of its members. In addition, the target setting to a certain extent depends on the availability of funds to achieve it. Naturally, in the conditions of differentiation of households, they possess these funds to varying degrees.

Neoclassic theory proceeded from the assumption of rational maximizing behaviour of individuals. The emphasis was made on the achieved equilibrium state or, in any case, movement towards it. For neoclassicism, the absence of chronic informational problems was typical. Meanwhile, complete rationality is the exception rather than the rule. In reality, limited rationality is more typical. In reality, individuals have rationality only to a limited extent. Intelligence is limited and, as a rule, there is a desire to save on it.

\section{Institutional approach}

\section{to the analysis of household economics}

Already being traditional, institutionalism tried to take into account the mentality while studying a specific society: a system of values, goals, stereotypes and habits of behaviour, psychological types and religious beliefs. An attempt to take into account the historical aspect of a particular society at a specific time of its development made it possible to bring the analysis closer to understanding real processes. Table 1 shows a comparative description of theoretical ideas about the rationality of individuals.

When analysing households, J. Hodgson draws attention to such factors as the scale of information, its complexity and uncertainty (Hodgson, 2003). He draws attention to the fact that households in their behaviour are guided by: a) habits; b) cheerfulness; c) pleasure associated with limited rationality; d) routines; e) average opinion.

The significance of the influence of routines on the behaviour of organizations in general and households in particular was shown in (Nelson, Winter, 2002: 138-188). Household behaviour takes into account personal interests, is influenced by the crowd (or society), and is modified under the influence of opportunism.

Along with the general principles of the rational consumer's choice, there are features that are determined by the influence of tastes and preferences on him. An American econo-

Table 1. Comparative characteristics of theoretical ideas about the rationality of individuals

\begin{tabular}{|c|c|c|c|}
\hline Feature & Economic man & Hybrid man & Institutional \\
\hline $\begin{array}{l}\text { 1. Approach to economic } \\
\text { theore }\end{array}$ & Neoclassical & by O. Williamson & Institutional \\
\hline 2. Purpose & Utility maximization & $\begin{array}{l}\text { Minimization of transac- } \\
\text { tion costs }\end{array}$ & Cultural knowledge \\
\hline $\begin{array}{l}\text { 3. Knowledge and compu- } \\
\text { tational capabilities }\end{array}$ & Unrestricted & Restricted & Restricted \\
\hline 4. Wishes & Defined independently & Defined independently & Defined by culture \\
\hline $\begin{array}{l}\text { 5. Dependence on the im- } \\
\text { pact of social factors }\end{array}$ & Independent & Independent & Not strictly dependent \\
\hline 6. Rationality & Full & Restricted & Cultural \\
\hline 7. Opportunism & $\begin{array}{l}\text { No deceit (cheat) and no } \\
\text { coercion }\end{array}$ & $\begin{array}{l}\text { There is deceit (cheat), but } \\
\text { no coercion }\end{array}$ & $\begin{array}{l}\text { There is deceit (cheat) and } \\
\text { coercion }\end{array}$ \\
\hline
\end{tabular}


mist H. Leibenstein (1950) divides consumer demand into two large groups: functional and non-functional.

Functional demand is such a part of demand, which is conditioned by consumer properties inherent in the economic good itself (product or service).

Non-functional demand is such a part of the demand that is caused by factors that are not directly related to the qualities inherent in an economic good. In non-functional demand, with a certain degree of conditionality, social, speculative and irrational factors can be distinguished. The first is related to the attitude of customers to the product. Some seek to maintain a common style and buy what their ideals buy. Others strive to achieve exclusivity rather than go with the flow. Finally, still others have reached a standard of living whose important part is demonstrative consumption. Therefore, $H$. Leibenstein identifies three typical cases of mutual influence.

1. The bandwagon effect. The consumer, trying to keep up with others, acquires what others buy. He depends on the opinions of other consumers, and this dependence is direct.

2. The snob effect. In this case, the consumer is dominated by the desire to stand out from the crowd. And here, an individual consumer depends on the choice of others, but this dependence is reverse. Therefore, the snob effect refers to the effect of a change in demand due to the fact that other people consume this product. Usually the reaction is directed in the opposite direction with respect to the generally accepted one.

3. The Veblen effect. So that is what H. Leibenstein calls prestigious or demonstrative consumption, when goods or services are not used for their intended purpose, but in order to make an indelible impression (Veblen, 1983).

The population explosion in developing countries has exacerbated the problem of poverty and has drawn attention to household economies, whose life expectancy has increased as a result of a sharp reduction in mortality and an increase in life expectancy of the population. As a result, many scientists began to study household economies in the third world, and above all, ways and methods of narrowing the gap that exists in per capita consumption of the population of poor and rich countries.

The early work of A. Deaton touched upon the problem of consumption and its effectiveness (Deaton, 1992, 1997). In the context of the population explosion, millions of people in Asia, Africa and Latin America faced the problem of survival. Therefore, the question naturally arose of how effectively those funds are used that are spent on food by various categories of the population. S. Subramanian and A. Deaton set themselves the task of considering the relationship between the total costs of economic agents and the nutritional properties of the products they consume (Subramanian, Deaton, 1996) ${ }^{2}$. S. Subramanian and A. Deaton came to an unexpected conclusion, showing that the cost of acquiring the calories needed for daily activity is less than $5 \%$ of wages per day.

In 2013, his monograph The Great Escape: Health, Wealth, and the Origins of Inequality was published (Deaton, 2013). The Great Escape is a story about how mankind tried to get rid of material deprivation and early death. In it, the scientist notes that over the past 250 years, mankind has made a powerful leap in the development of health care and improving the well-being of people. And although not everyone was able to escape, and not everyone was ready to take advantage of the luck that had opened up for them, he speaks of the great progress that mankind has experienced over the past 50 years. We see that in recent years, scientists that are more interested in the problems of developing countries than developed ones have been engaged in household economies.

The works of the 2019 Nobel laureates A. Banerjee, E. Duflo (Banerjee, Duflo, 2011; Duflo, 2012) and M. Kremer (1993) took into account this experience, but are not limited to it and find new methods to increase the effectiveness of the fight against poverty. The focus of research on new Nobel laureates is not theory, but practice. To this end, they use a randomized approach. Since it is very difficult to set up a controlled experiment, scientists are forced to rely mainly on observations. To this end, they

\footnotetext{
The materials of this article were later included in the $4^{\text {th }}$ chapter of the monograph (Deaton, 1997: 200-222).
} 
compare the results of the control sample with the sample in which the experiment takes place.

The focus of their attention is a study of the effectiveness of the assistance provided by international organizations to developing countries. In particular, the new Nobel laureates prove that the means to combat poverty must be sought together with the recipients of this assistance. This allows you to dramatically increase its effectiveness.

\section{Institutional analysis of households} in transition economy

A transition economy is a changing, "transforming" society. And household behaviour in a "changing society" includes:

A) Changes in the degree of rationality of behaviour;
B) Changes in the degree of pursuit of personal interests;

C) Changes in the degree of activity orientation to market relations.

The modern economy of Russian households is the result of the transition from a natural planned economy, on the one hand, to a market economy, on the other hand. However, the latter includes both legal and illegal economies. Under these conditions, an institutional analysis of household behaviour is extremely important because it not only takes into account the influence of the institutional space as a limiter on household actions, but also shows how this space is gradually changing under the influence of their actions. One of the first attempts at such a generalized analysis was made by A.N. Oleinik (2002, lecture No. 23).

Table 2. Institutional changes in households in post-Soviet Russia

\begin{tabular}{|c|c|c|c|c|c|}
\hline \multirow[b]{2}{*}{ Features } & \multirow[b]{2}{*}{$\begin{array}{c}\text { Source } \\
\text { state } \\
\text { in the USSR }\end{array}$} & \multicolumn{4}{|c|}{ Changes in Post-Soviet Russia } \\
\hline & & $\begin{array}{l}\text { Expected } \\
\text { by Radical } \\
\text { Reforms }\end{array}$ & $\begin{array}{l}\text { Actually oc- } \\
\text { curred } \\
\text { in the period } \\
\text { of the } 1990 \mathrm{~s} \text {. }\end{array}$ & $\begin{array}{l}\text { Actually occurred } \\
\text { in the } 2000 \mathrm{~s} .\end{array}$ & $\begin{array}{l}\text { Really } \\
\text { happened in } \\
\text { the } 2010 \mathrm{~s} \text {. }\end{array}$ \\
\hline $\begin{array}{l}\text { Interperson- } \\
\text { al trust }\end{array}$ & Relatively high & High & Low & $\begin{array}{l}\text { Gradual return to } \\
\text { the previous level }\end{array}$ & Slowed down \\
\hline $\begin{array}{l}\text { Type of } \\
\text { employee }\end{array}$ & $\begin{array}{l}\text { "Cog work- } \\
\text { ers" - ex- } \\
\text { ecutive and } \\
\text { non-initiative }\end{array}$ & $\begin{array}{l}\text { Creative } \\
\text { worker of the } \\
\text { "American" } \\
\text { type (mobile) }\end{array}$ & $\begin{array}{l}\text { "Snail Peo- } \\
\text { ple", caring } \\
\text { only about } \\
\text { self-survival }\end{array}$ & $\begin{array}{l}\text { Executive worker } \\
\text { of the "Japanese" } \\
\text { type (immobile), } \\
\text { hesitating between } \\
\text { paternalism and } \\
\text { individualism } \\
\end{array}$ & $\begin{array}{l}\text { A slight } \\
\text { increase in } \\
\text { mobility }\end{array}$ \\
\hline $\begin{array}{l}\text { Consumer } \\
\text { behavior }\end{array}$ & $\begin{array}{l}\text { The pursuit } \\
\text { of "deficit" }\end{array}$ & $\begin{array}{l}\text { Creation of } \\
\text { a "consumer } \\
\text { society" }\end{array}$ & $\begin{array}{l}\text { The contrast be- } \\
\text { tween prestig- } \\
\text { ious consump- } \\
\text { tion and forced } \\
\text { asceticism }\end{array}$ & $\begin{array}{l}\text { Gradual smooth- } \\
\text { ing of contrasts, } \\
\text { consumer boom }\end{array}$ & $\begin{array}{l}\text { Deteriorating } \\
\text { nutritional } \\
\text { structure }\end{array}$ \\
\hline $\begin{array}{l}\text { Investment } \\
\text { behavior }\end{array}$ & Almost absent & $\begin{array}{l}\text { Development } \\
\text { strategy }\end{array}$ & $\begin{array}{l}\text { Survival } \\
\text { strategy }\end{array}$ & $\begin{array}{l}\text { Shift from "living } \\
\text { within our means" } \\
\text { to "debt lifestyle" }\end{array}$ & $\begin{array}{l}\text { From fixtures } \\
\text { to market } \\
\text { development }\end{array}$ \\
\hline $\begin{array}{l}\text { Domestic } \\
\text { corruption }\end{array}$ & Widespread & Absent & $\begin{array}{l}\text { Very wide- } \\
\text { spread }\end{array}$ & Tended to increase & $\begin{array}{l}\text { Remained at } \\
\text { the same level }\end{array}$ \\
\hline $\begin{array}{l}\text { Society } \\
\text { structure }\end{array}$ & $\begin{array}{l}\text { The predom- } \\
\text { inance of } \\
\text { the "Soviet" } \\
\text { middle class }\end{array}$ & $\begin{array}{l}\text { The dominance } \\
\text { of the "market" } \\
\text { middle class }\end{array}$ & $\begin{array}{l}\text { The sharp } \\
\text { polarization } \\
\text { of society }\end{array}$ & $\begin{array}{l}\text { The middle class in } \\
\text { the proper sense of } \\
\text { the word is small }\end{array}$ & $\begin{array}{l}\text { No significant } \\
\text { changes }\end{array}$ \\
\hline Civil society & Absent & $\begin{array}{l}\text { It plays the role } \\
\text { of one of the ba- } \\
\text { sic institutions }\end{array}$ & $\begin{array}{l}\text { Demand for sel } \\
\text { institutions are }\end{array}$ & $\begin{array}{l}\text { overnment is defe } \\
\text { trusted by either }\end{array}$ & $\begin{array}{l}\text { d; civil society } \\
\text { zens or the state }\end{array}$ \\
\hline
\end{tabular}


Compiled and supplemented by: (Economic entities..., 2010: 15).

National economic mentality (business culture) includes: 1) stereotypes of consumption; 2) norms and patterns of interaction; 3) organizational forms; 4) value-motivational attitude to work and wealth; 5) the degree of susceptibility (or immunity) to foreign experience.

The Russian mentality is characterized by communality and community that means considering man as part of the whole. The tendency to humility usually prevents the isolation of the individual as an autonomous agent. The processes of reciprocation and redistribution that existed in Russia played an important role in this. Hence is the absolutization of moral values as opposed to material ones, the low ranks of active-attaining values. Saving and ownership have traditionally been seen as negative values. A certain contribution to this was made by Russian Orthodoxy. From the point of view of a Russian, success is luck and the result of luck, as well as the result of personal connections. Hence is the naive belief in quick enrichment. Therefore, freedom was perceived by the average Russian as anarchy (not as independence, but the ability to do what one wants). Therefore, the reaction of a significant part of the population to the difficulties of transition to a market economy was not adaptation to it, but flight from it.

Depending on the adaptation to the market, a polarization of society took place. It broke up into those who adapted to the market economy, and those who were unable to adapt to it immediately. M.A. Shabanova divided the first group into two categories: progressive and regressive adaptants (Economic entities..., 2003, ch. 3).

Progressive adaptants rely on themselves; they value higher such rights as creating their own business, freedom of movement, and upholding their own views. On the contrary, those who failed to adapt to a market economy (nonadaptants) are much more likely to assess employment guarantees, income provided by the state, timely payment of wages, free education, and free medical care. Between them were those whom M.A. Shabanova calls regressive adaptants. They adapted to a market economy, but for this they had to make significant changes in their profession, work and lifestyle.

According to M.A. Shabanova, the gap between the declared, desired and realized freedom led to the fact that deviation from legal norms has become a kind of norm of behaviour, and following them is an exception. This caused the criminalization of society, the development of non-legal freedom, when the violation of new formal rules becomes a new informal rule. As a result, in the mid-1990s, Russian society was further away from Western institutional legal freedom than it had been on the eve of the reforms.

Yu.V. Latov proposed comparing institutional changes in households, firms, and the state in a tabular form (Economic Entities..., 2010). We continued his approach (see Table 2). The table shows that the situation in the 2010s did not change significantly compared to the 2000s. This can be seen from Table 3, which shows the distribution of cash incomes of the population from 1970 to 2018 (see Table 3).

Table 3. The distribution of cash incomes of the Russian population in 1970-2018

\begin{tabular}{|l|c|c|c|c|c|c|c|}
\hline & 1970 & 1980 & 1990 & 1995 & 2000 & 2010 & 2018 \\
\hline The 1st quintile (with the lowest income) & 7.8 & 10.1 & 9.8 & 5.5 & 6.0 & 5,2 & 5,3 \\
\hline The 2nd & 14.8 & 14.8 & 14.9 & 10.2 & 10.4 & 9,8 & 10,0 \\
\hline The 3rd & 18.0 & 18.6 & 18.8 & 15.0 & 14.8 & 14,8 & 15,0 \\
\hline The 4th & 22.6 & 23.1 & 23.8 & 22.4 & 21.2 & 22,5 & 22,6 \\
\hline $\begin{array}{l}\text { The 5th } \\
\text { (with the highest income) }\end{array}$ & 36.8 & 33.4 & 32.7 & 46.9 & 47.6 & 47,7 & 47,1 \\
\hline Gini coefficient & $\ldots$ & $\ldots$ & $\ldots$ & 0.381 & 0.399 & 0,421 & 0,413 \\
\hline
\end{tabular}

Source: Federal State Statistics Service. Available at: https://www.gks.ru/folder/13397?print=1 
In connection with the introduction of economic sanctions in the second half of this decade, there has been an increase in prices. The average consumer feels the burden of economic sanctions against Russia in the form of rising prices for consumer goods and nonessential goods (Nureev, 2019, ch. 4). As a result, the living costs level in the country rose sharply for the working-age population as a whole and for retired population in particular, since the cost of food accounted for about half the consumer basket value (see Fig. 1)

The increase in food prices caused by sanctions led to inflation (see Fig. 2). All this resulted in a decrease in real incomes in general and especially of the poorest $40 \%$ of the population (World Bank..., 2016: 23).

\section{Conclusion}

Two forecasts of the near future developments are possible from the point of

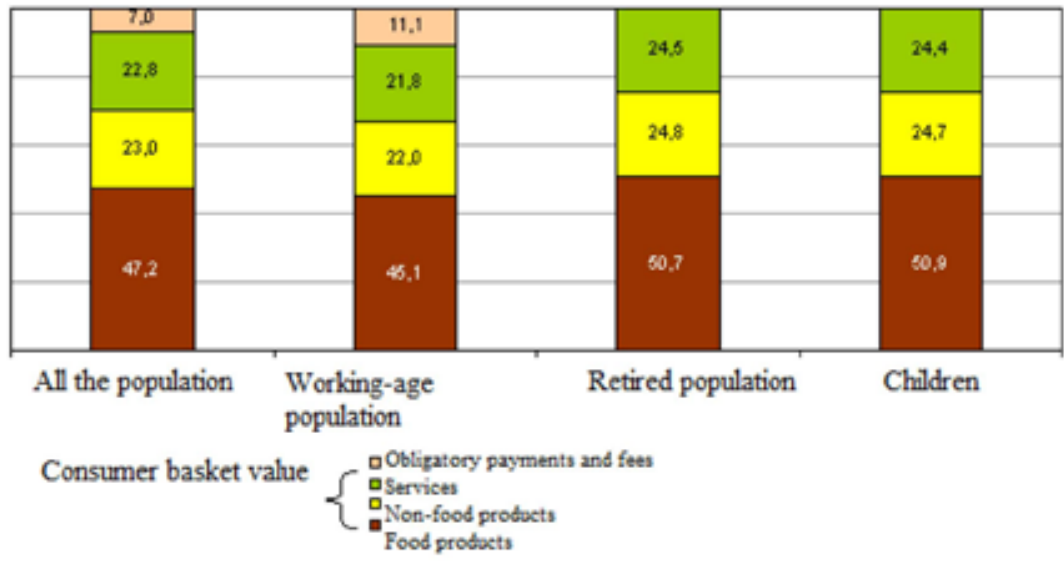

Fig. 1. The structure of the subsistence minimum by population groups in the the $1^{\text {st }}$ quarter of 2015 (in \%). Available at: http://www.gks.ru/bgd/free/b04_03/IssWWW.exe/Stg/d05/image5115.gif

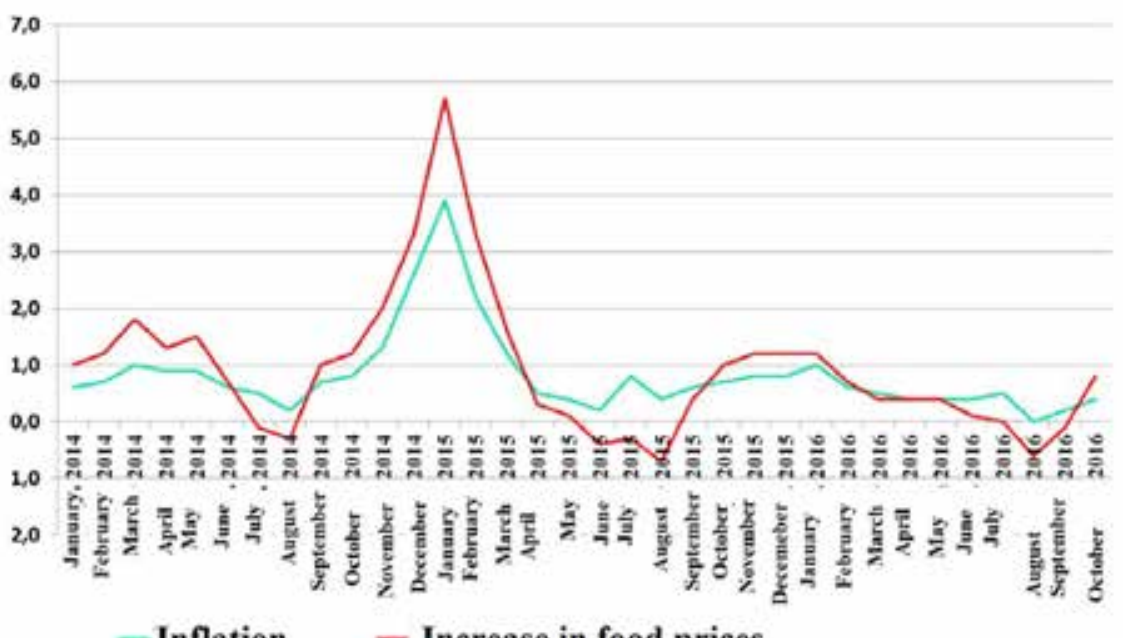

\section{-Inflation - Increase in food prices}

Fig. 2. The growth rate of food prices and inflation in 2014-2016 (\% to the previous month). Available at: http://www.cbr.ru/statistics/infl/Infl_01102016.pdf 
view of the ordinary consumer: pessimistic and optimistic (for more details see Nureev, 2019: 138-139). The prerequisites for the development of a pessimistic forecast are the further strengthening of economic sanctions and the continued decline in oil prices. In this case, there will be a deepening of Russia's economic isolation from the world community. Sanctions may include the suspension of Visa and MasterCard in Russia and the further development of an alternative MIR system. Under these conditions, Russia will seek allies in the face of the BRICS countries and, above all, China. This will objectively create further prerequisites for the transition from a unipolar world to a multipolar one. Any steps in this direction can lead to consequences that many partic- ipants in the economic conflict in the short term are not even aware of.

The prerequisites for the development of an optimistic forecast are rising oil prices and the weakening of economic sanctions. This will lead to the strengthening of the Russian rubble, which will create great opportunities for increasing imports, as it will make it cheaper. The weakening of economic sanctions will restore relations with Western Europe and then there will be a shift from East to West, as the share of West European goods will increase in Russian imports. This will allow diversifying commodity flows and choosing as a partner those countries that provide the most favoured nation treatment for Russia. However, in this case, competition of imported goods with domestic ones will intensify.

\section{References}

Banerjee, A., Duflo, E. (2011). Poor economics: a radical rethinking of the way to fight global poverty. NY. Public Affairs.

Deaton, A. (1992). Understanding Consumption. Clarendon Press. Oxford.

Deaton, A. (1997). The Analysis of Household Surveys: A Microeconometric Approach to Development Policy. Washington, D.C.

Deaton, A. (2005). Data and Dogma: The Great Indian Poverty Debate. The World Bank Research Observer.

Deaton, A. (2013). The Great Escape: Health, Wealth, and the Origins of Inequality. Princeton University Press.

Duflo, E. (2012). Human values and the design of the fight against poverty. Tanner Lectures. Available at: http://economics.mit.edu/files/7904

Economic entities of post-Soviet Russia (institutional analysis) (2003). Part I. Moscow, MONF.

Economic entities of post-Soviet Russia (institutional analysis): ten years after (2010). Part III. The Russian state. Moscow, MONF.

Federal State Statistics Service. Available at: https://www.gks.ru/folder/13397?print=1

Friedman, D. (1986). Price Theory. An Intermediate Text. South-Western Pub Co., ch. 3, 4, 36-98.

Friedman, M. (1957). A Theory of the Consumption Function Princeton: Princeton University Press.

Hicks, J.R. (1988). Cost and capital. Moscow, Progress, ch. I-III, 103-148.

Hodgson, J. (2003). Economic theory and institutions. Moscow, Delo.

Keynes, J.M. (1978). The General Theory of Employment, Interest, and Money. Moscow, Progress.

Kremer, M. (1993). The O-Ring Theory of Economic Development. In Quarterly Journal of Economics, 108 (3), 551-575.

Leibenstein, X. (2000). The effect of joining the majority, the snob effect and the Veblen effect in the theory of consumer demand. In Theory of consumer behavior and demand Milestones of economic thought. Saint-Petersburg, 1, 304-325.

Marshall, A. (1993). Principles of economic science. Moscow, Progress, vol. 1, book III, ch. 1-4, 145182.

Menger, K., Böhm-Bawerk, E., Wieser, F. (1992). The Austrian school in political economy. Moscow, Economics. 
Modern economic thought (1981). Moscow, Progress, ch. 12, 317-358.

Modigliani, F. (1970). The life-cycle hypothesis of saving and inter-country differences in the saving ratio. Oxford: Clarendon Press, 197-225.

Molenvo, E. (1985). Lectures on microeconomic analysis. Moscow, Nauka, ch. II, 23-51.

Nelson, R., Winter, S. (2002). The evolutionary theory of economic change. Moscow, Delo.

Nureev, R.M., ed. (2010). Economic entities of post-Soviet Russia (institutional analysis). 10 years later. Parts I, II, III. Moscow, MONF.

Nureev R.M., ed. (2019). Economic sanctions against Russia: expectation and reality. Moscow, KNORUS.

Nureev, R.M. (1995). Money, Banks, and Monetary Policy: A Study Guide. Moscow, Finstatinform.

Nureev, R.M. (2014). The course of microeconomics. 3rd ed. Moscow, Norma: INFRA-M.

Oleinik, A.N. (2002). Institutional Economics. Moscow.

Seligman, B. (1968). The main trends of modern economy: economic thought. Moscow, Progress.

Stoleru, L. (1974). Equilibrium and economic growth: (principles of macroeconomic analysis. Moscow, Statistics. 472 p.

Subramanian, S., Deaton, A. (1996). The Demand for Food and Calories. In Journal of Political Economy, 104 (1).

The theory of consumer behavior and demand. Milestones of economic thought (2000). Vol. 1, Saint-Petersburg.

Veblen, T. (1983). Theory of the idle class. Moscow, Progress. 


\title{
Домохозяйства постсоветской России (институциональный анализ): 20 лет спустя
}

\author{
P.M. Нуреев \\ Департамент «Экономическая теория» \\ Финансового университета при Правительстве РФ \\ Российская Федерация, Москва \\ Национальный исследовательский университет \\ «Высшая школа экономики» \\ Российская Федераичия, Москва
}

\begin{abstract}
Аннотация. В статье рассматривается развитие взглядов на домохозяйства в неоклассической, кейнсианской и институциональной литературе. Показываются достоинства и недостатки каждого из этих подходов. Неоклассики не проводят различия между индивидами и домашними хозяйствами. Кейнсианство проанализировало инвестиционно-сберегательную функцию домашних хозяйств, показало ее роль в кругообороте доходов и расходов. Однако оно не поднялось до подлинной политической экономии, поскольку не сумело показать особенности поведения основных социальных групп и присущих им интересов. Шаг вперед делает институциональная экономическая теория, показывая зависимость домашних хозяйств от социальной среды. Однако реальные домохозяйства ограничены в сборе и обработке информации. Тем более в условии дифференциации домашних хозяйств они обладают этими средствами в разной степени.

Демографический взрыв в развивающихся странах обострил проблему бедности и привлек внимание к экономике домашних хозяйств, продолжительность жизни которых увеличилась в странах Азии, Африки и Латинской Америки в результате резкого сокращения смертности и увеличения продолжительности жизни населения.

Специальный раздел посвящен институциональному изменению домашних хозяйств в постсоветской России. Показывается, чего удалось и чего не удалось достичь за последние тридцать лет.
\end{abstract}

Ключевые слова: домашние хозяйства, потребление и сбережения, инвестиции домашних хозяйств, переходная экономика, экономические санкции, инвестиционно-сберегательная функция домашних хозяйств.

Статья подготовлена по результатам исследований, выполненных за счет бюджетных средств по государственному заданию Финансового университета при Правительстве РФ по теме «Семейные домохозяйства как экономический субъект».

Научная специальность: 08.00.00 - экономические науки. 